\title{
Prevalence of Anaemia in Jenukuruba Primitive Tribal Children of Mysore District, Karnataka
}

\author{
S.C. Jai Prabhakar and M.R. Gangadhar \\ Department of Anthropology, University of Mysore, Manasagangotri, \\ Mysore 570 006, Karnataka, India \\ E-mail: gangadharmr@yahoo.com,gangadharmr@gmail.com
}

KEYWORDS Jenukuruba. Tribal Children. Anaemia. Haemoglobin

\begin{abstract}
A study on the prevalence of anaemia was conducted among Jenukuruba primitive tribal children of Mysore district, Karnataka state. For the present study 175 children ranging in age group 6-10 years were selected and estimated the haemoglobin level by cyanmethaemoglobin method. The study revealed that, $36.57 \%$ of children were moderately anaemic, 26.29 per cent were mildly anaemic and 14.86 percent severely anaemic. On the whole $77.71 \%$ were suffering from different forms of anaemia. Prevalence of anaemia was more among the girls than boys.
\end{abstract}

\section{INTRODUCTION}

Children are the wealth of any country. The children are major components of the population composition and from the nutritional point of view they constitute a vulnerable group. This vulnerability is easy susceptibility to malnutrition and infection.

Nutritional anaemia is one of the important public health problem in India and many parts of the world. Anaemia is a useful index of the severity of iron deficiency, but the significant liabilities of iron deficiency are more related to a deficiency in tissue iron. The major consequences of iron lack include impaired growth, development of delay and behavioral abnormalities, and impair cognitive functions (ICMR 1977).

Incidence of anaemia is quite prevalent among 6 to 10 years aged children and they usually do not benefit from any of the micro nutrient intervention programmes for they are focused on preschoolers, pregnant and lactating women. Micronutrient intervention is necessary for this age group also (Rajagopalan 2003). Keeping all this in view an attempt has been made to assess the prevalence of anaemia among the Jenukuruba children.

Jenukuruba is a primitive tribe in Karnataka. They were distributed in Mysore, Kodagu and dispersed in other district in smaller concentration. The distribution mostly in rehabilitated settlements and very few of them are inside the forest. The term Jenu means 'Honey' and kuruba indicates their caste name. (Gupta 2003) They are honey collectors and food gatherers. Their speech called "Jenunudi" is a dialect of distorted version of Kannada. Consanguineous marriages are more common among them and follow monogamy. Early marriages are common in both males and females. In case of death, children are buried and adults are burned. They believe in magic, sorcery and witchcraft. Ragi is their main staple food. Turdal is used very frequently than other pulses.

Economy is based on honey collection, agricultural labour, crude agriculture level of technology and occasionally hunting and gathering of minor forest produces. Both male and females are addiction to liquor, minor vice like beetel chewing, smoking etc. Almost all the colonies are provided with basic amenities like housing, drinking water, electricity, drainage etc. but the land allotted to them is barren or uncultivable. Though most of the colonies are provided with bore wells, water scarcity is acute during summer season.

\section{MATERIAL AND METHODS}

For the present study 175 children ranging in age between 6-10 years were selected purposefully. All the children between the ages 6.00-6.99 were included in 6+ age group, 7.00 to 7.99 in the age group 7+, and so on up to $10+$ (Sidhu et al. 2007). The blood sample obtained by finger prick and were analysed for haemoglobin estimation by cyanmethaemoglobin method of Dacie and Lewis (1975). Different grades of anaemia were diagnosed when haemoglobin concentration was less than $12 \mathrm{~g} /$ dl for the children (NIN 1986). 


\section{RESULTS AND DISCUSSION}

It is appeared from Table1 that, only $22.29 \%$ children were normal and $77.71 \%$ were affected with various grades of anaemia. $26.29 \%$ being mildly anaemic, $36.57 \%$ were moderately anaemic and $14.86 \%$ suffered from severe anaemic. The similar findings of an earlier study conducted by Sharma (1998) among Hill Korwa tribal children of Madhya Pradesh and reported $98.89 \%$ were anaemic condition. DeMaeyer (1989) found that 93.5 per cent children were anaemic having haemoglobin level below $11.5 \mathrm{~g}$ percent. Sidhu (1997) study reveals that, $95.65 \%$ of the scheduled caste children of Amritsar were affected with various grades of anaemia. Sidhu et al. (2002) also indicated a high prevalence $(81.66 \%)$ of anaemia in scheduled caste preschool children of Punjab. Agarwal et al. (1989) studied rural primary school children of Varanasi and reported the prevalence of $93 \%$ anaemia. Vyas and Choudhry (2005) also indicated that 93.7 per cent of tribal children of Rajasthan were suffering from different forms of anaemia. From the present and earlier studies were shown, more prevalence of anaemia among tribal, rural and scheduled caste children.

There was an age differential in the prevalence of anaemia among Jenukuruba children. A higher proportion $(89.36 \%)$ of the children were anaemic in the 9+ age group followed by $8+(82.76)$ and so on. Although more of the girls were suffering from anaemic condition than boys. The percentage difference of normal shows $29.11 \%$ and $16.67 \%$ among boys and girls respectively. But no girls found to be normal in the age group of $8+$ years. A mild form of anaemia was present in $25 \%$ of female and $27.85 \%$ of males. $40.63 \%$ of female children suffered from moderate anaemia compared to $31.65 \%$ males. Severity among girls was $17.71 \%$ and among boys
$11.39 \%$. So, more number of children were suffered from moderate anaemia than mild and severe grades of anaemia.

The results of earlier studies were also said about the children suffering from different grades of anaemia. DeMaeyer (1989) reported that 60.2 per cent children were suffering from moderate, 32.9 per cent severe and 0.06 per cent from mild anaemia. Sarma et.al. (1992) study indicated that $54.5 \%$ of Orissa children were suffering from mild, 27.2 per cent moderate and only 2.7 per cent severe type of anaemia. In a study by Swami et al. (1998) indicated an overall prevalence of anaemia to be $54.70 \%$ with more of females $(67.70 \%)$ suffering from it rather than their males (32.30\%).

\section{CONCLUSION}

The present study reveals high frequency of anaemia among the Jenukuruba tribal children may be due to higher dietary inadequacy of all nutrients including iron. The Jenukuruba children consumed mainly cereal-based diet and associated with lack of safe drinking water, poor knowledge on the part of the mother regarding nutritional requirement of the children. Poverty and illiteracy are the main causative factors for all.

\section{REFERENCES}

Agarwal DK, Upadhyay SK, Agarwal KN, Singh RD, Tripathi AM 1989. Anaemia and Mental functions in rural primary school children. Ann Trop Paediatr, 9: 194-198.

Dacie JV, Lewis SM 1975. Practical Hematology. Great Britain: Churchill Living Stone, Edinburgh.

DeMaeyer EM 1989. Preventing and controlling Iron Deficiency Anaemia through Primary Health Care. Geneva: World Health Organization.

ICMR 1977. Studies on Preschool Children. Technical Report, Series. No. 26, New Delhi: ICMR.

Table 1: Number and percentage prevalence of different grades of anaemia among Jenukuruba children

\begin{tabular}{|c|c|c|c|c|c|c|c|c|c|c|c|}
\hline \multirow{2}{*}{$\begin{array}{l}\text { Age } \\
\text { group }\end{array}$} & \multirow{2}{*}{$\begin{array}{c}\text { No.of } \\
\text { subject }\end{array}$} & \multicolumn{2}{|c|}{ Normal } & \multicolumn{2}{|c|}{ Anaemic } & \multicolumn{2}{|c|}{ Mild } & \multicolumn{2}{|c|}{ Moderate } & \multicolumn{2}{|c|}{ Severe } \\
\hline & & No. & $\%$ & No. & $\%$ & No. & $\%$ & No. & $\%$ & No. & $\%$ \\
\hline $6+$ & 35 & 9 & 25.71 & 26 & 74.29 & 5 & 14.29 & 15 & 42.86 & 6 & 17.14 \\
\hline $7+$ & 50 & 15 & 30.00 & 35 & 70.00 & 10 & 20.00 & 20 & 40.00 & 5 & 10.00 \\
\hline $8+$ & 29 & 5 & 17.24 & 24 & 82.76 & 10 & 34.48 & 9 & 31.04 & 5 & 17.24 \\
\hline $9+$ & 47 & 5 & 10.64 & 42 & 89.36 & 16 & 34.04 & 17 & 36.17 & 9 & 19.15 \\
\hline $10+$ & 14 & 5 & 35.71 & 9 & 64.29 & 5 & 35.72 & 3 & 21.43 & 1 & 7.14 \\
\hline Total & 175 & 39 & 22.29 & 136 & 77.71 & 46 & 26.29 & 64 & 36.57 & 26 & 14.86 \\
\hline Girls & 96 & 16 & 16.67 & 80 & 83.33 & 24 & 25.00 & 39 & 40.63 & 17 & 17.71 \\
\hline Boys & 79 & 23 & 29.11 & 56 & 70.89 & 22 & 27.85 & 25 & 31.65 & 9 & 11.39 \\
\hline
\end{tabular}


NIN 1986. Anaemia in Endurance capacity (Physical Performance). Annual Report. pp. 164-165, Hyderabad: NIN (ICMR).

Gupta R 2003. Jenu Kuruba. In: KS Singh (Ed.): People of India: Karnataka. New Delhi: Anthropological Survey of India. Affiliated East-West Press Pvt. Ltd, Vol.26, Part 2.

Rajagopalan S 2003. Towards Malnutrition Free Tamil Nadu: $30^{\text {th }}$ Annual Session of United Nations Standing Committee on Nutrition, Task force Report. Chennai.

Sarma KVR, Brahmam GNV, Reddy CG, Ravindranath M, Rao NP 1992. Iron fortified Salt distribution through integrated child development services in Orissa-an assessment. Asia Pac J Clin Nutr, 1: 239-243.

Sharma KKN 1998. Assessment of Haemoglobin Level Among the Hill Korwa Primitive Tribal Children of Madhya Pradesh, India. J Hum Ecol, 9 : 525526.

Sidhu S 1997. Prevalence of Anaemia in Scheduled Caste Children of Mahl Village in Amritsar District of Punjab. J Hum Ecol, 8: 495-497.

Sidhu S, Kumari K, Uppal M 2002. Prevalence of anaemia in Scheduled Caste Preschool children of Punjab. Ind J Med Sci, 56: 218-221.

Sidhu S, Kumari K, Uppal M 2007. Prevalence of anaemia in Bazigar (Ex-nomadic Tribe) Preschool Children of Punjab. J Hum Ecol, 21: 265-267.

Swamy MM, Thakur JS, Bhatia SPS 1998. Prevalence of anaemia in rural area of Chandigarh. Ind J Mat Child Health, 9: 62-64.

Vyas S, Choudhry M 2005. Prevalence of Anaemia in Tribal School Children. J Hum Ecol, 17: 289-291. 